\title{
Dossiê Temático: Sim, Língua Estrangeira se aprende na escola
}

Henry Daniel Lorencena Souza*

Rosália Lacerda ${ }^{* *}$

A partir das transformações que a sociedade tem sofrido nas últimas décadas, a percepção sobre o ensino de línguas também mudou e a escola passou a ser o espaço para o desenvolvimento de metodologias de ensino que permitam a sua aprendizagem. Por isso, é com grande orgulho que apresentamos, nesta edição do Cadernos do Aplicação, dossiê sobre o ensino de línguas estrangeiras na Educação Básica, mostrando diferentes olhares sobre o papel que o ensino de idiomas desempenha na escola e as contribuições que pode oferecer para as demais áreas do conhecimento.

Além de ampliar o acesso à informação, disponível entre outros meios, através das tecnologias digitais, conhecer uma língua e uma cultura estrangeiras tem um objetivo muito maior, qual seja: conhecer novas formas de ver e entender o mundo, promovendo ao indivíduo a reflexão sobre si mesmo e a validação do diferente. Se, no passado, aprender uma língua era privilégio de poucos, no presente, essa aprendizagem é imprescindível. Saber uma ou várias línguas estrangeiras é a garantia da democratização da informação, pois portas se abrem a novas fontes, a diferentes pontos de vista e a oportunidade de colocar-se no lugar do outro.

Nessa procura por condições mais adequadas de construção de um espaço no qual a aprendizagem de línguas pudesse dialogar com a aquisição, muitos modismos surgiram tentando

Professor de Espanhol do CAp/UFRGS. E-mail: hdls@uol.com.br

** Professora de Espanhol do CAp/UFRGS. E-mail: rosalia_lacerda@yahoo.com.br 
dar nomes diferentes que justificassem novas práticas. Na confusão de conceitos que acabam circulando no contexto escolar, acompanhamos a transformação da Lingua Estrangeira em Lingua Adicional, como se de um mesmo processo se tratasse. Cabe esclarecer que o termo "Língua Adicional" surgiu a partir de um estudo financiado pelo Conselho de Europa, visando incluir nos currículos escolares europeus as línguas não oficiais, sejam elas regionais, minoritárias ou de imigração. Portanto, não se trata de substituir o nome da disciplina, mas sim de adequar o ensino de línguas nos diferentes contextos. Assim, nas regiões de fronteira, o Espanhol pode vir a ser uma língua adicional, da mesma forma que o Alemão nas zonas de imigração alemã. Nos contextos urbanos, no entanto, é notório que as grandes línguas de comunicação internacional continuam sendo estrangeiras. E, se tratando de línguas estrangeiras, é importante o desenvolvimento de estratégias de ensino que permitam na Educação Básica o desenvolvimento da Competência Comunicativa (entendida como o resultado da soma de outras competências: a discursiva, a gramatical, a sociolinguística, a sociocultural e a estratégica).

É com essa reflexão que convidamos os leitores a percorrerem os diferentes artigos aqui publicados, pois todos servem de guia para entender o ensino de línguas no contexto escolar, fundamental para a formação de uma consciência cidadã aberta a novos horizontes que atenda as exigências de um mundo multicultural e plurilíngue. 